\title{
Determinants of Extension Service Needs Of Catfish Farmers in Oyo State, Nigeria (A case study of Ido local Government Area.)
}

\author{
${ }^{1}$ Adebayo, Oyefunke Olayemi. \\ Department of Agricultural Economics and Extension, Ladoke Akintola University of Technology Ogbomoso, \\ Nigeria.
}

\begin{abstract}
The Study examined extension service needs of catfish farmers in Oyo State. Specifically, it examined socio economic characteristics, sources of information as well as extension service needs and constraints encountered by catfish farmers. Primary data were obtained from 120 respondents using multistage random sampling technique by means of structured questionnaire. Analysis of data was done using frequency counts; percentages, mean scores and PPMC statistics. The study showed that most (70.6\%) of the respondents were male whose age range between 30 and 50 years. Majority (74.8\%) of the respondents identified radio programmes as sources of information. The major problems encountered by respondents include poor weather $82.5 \%$, lack of credit facilities (76.7\%) inadequate extension contact $(71.7 \%)$. The results of tested hypothesis showed that age, gender and year of schooling was significantly related to extension services needs. The study recommended that provision of effective extension service to disseminate relevant and timely information technologies to catfish farmer should be encouraged.
\end{abstract}

Keywords: Extension, needs, Catfish, determinants

\section{Introduction}

Captured fisheries accounted for about $97 \%$ of the bulk of the total fish production, while cultured fisheries contributed a mere 3\% of the fish produced in the country in the last decade (Federal Department of Fisheries, FDF 1995). According to Wurts (2004) small scale and homestead catfish farming are significantly more sustainable than intensive production, because inputs are minimize and cost of production are substantially reduced. Fish farming is the world's fastest growing source of animal food, outpacing terrestrial meat production and the captured fisheries (FAO, 1991). Fish processing and marketing in Nigeria enjoy wide spread acceptability since no religious or cultural belief place any taboo against it (Ala and Umar 2002).

The extension service has a vital role of increasing and improving fish production through their linkage between researchers and end-users. Without extension services most research endeavour will be futile exercise (Adebolu and Ikotun 2001) According to Akinbode (1982) rather than engage in direct production, the Agricultural Development (ADP) was designed to stimulate and motivate small-scale farmers to the use of modern techniques of fish farming through farm extension education. However, with shortage of extension personnel, the inaccessibility of large numbers of farmers living in rural areas and poor communication infrastructure, farmers' access to information has been limited. Poor extension services due to low contact with farmers have been reported. Agbamu (1998) noted that poor performance of extension services was due to low extension agent farmers ratio; which is 1:2100 in Edo State, 1:2131 in Ogun State, 1:16917 in Oyo State, 1:1496 in Lagos State Adebowale et al; (2006).

Nigeria has potential to expand its fisheries if properly managed. The nation's annual yield is estimated to be $1: 830994 \mathrm{~m}$ tons in the nineties (Adedokun, 2005). Agricultural extension service is widely recognised as the mechanism for the delivery of proven information and advice to farmers for improved productivity. With adequate and relevant information required for improved production, there will be opportunity to earn more income for improved living. It is against this background that this study sought to investigate the extension service needs of Catfish farmers in the study area.

Objectives of the study: The major objective is to determine the extension service needs of Catfish farmers in the study area. The specific objectives are to:

(i) identify the socio-economic characteristics of catfish farmers in the study area.

(ii) investigate the various sources of information available to catfish farmers.

(iii) determine the extension service needs of catfish farmers.

(iv) identify the constraints militating against catfish production in the study area.

Hypothesis of the study: There is no significant relationship between socio-economic characteristics of catfish farmers and extension service needs. 


\section{Methodology}

The Study was carried out in Ido Local Government Area of Oyo State, Oyo State is an inland state in South-Western Nigeria, with its capital at Ibadan. It is bounded in the north by Kwara State, in the east by Osun State, in the South by Ogun State and in the West partly by Ogun State and partly by the Republic of Benin. Ido Local Government is surrounded by forest reserve such as Ijaye forest Reserve. It has an area of $986 \mathrm{~cm}^{3}$ and a population of 103,261 at the 2006 census. The population of the study consists of Catfish farmers living in the study area. The people of the study area are predominantly subsistence farmers. Crop grown include tubers, cereals, cassava and guinea corn; sheep and goat poultry, cattle, fish can also be found in a sizeable number. Nonfarm activities and civil service jobs can be found in the area. A list of registered catfish farmers was collected from the local government headquarters. The list of catfish farmers were extracted from the register and a systematic random sampling technique was used to select 120 catfish farmer from the list. The data for this study were collected from primary sources through the use of structured questionnaire containing both open ended and closed ended questions. The questionnaire elicited information on respondents' socio-economic characteristics, sources of information, and extension services needs. The dependent variable of the study is the extension service needs, measured on a three point scale to indicate the degree of his/her information of Catfish production needs. The three points scale was weighted as follows: $0=$ Not well informed, $1=$ averagely informed and $2=$ very well informed. The mean score of extension needs for each aspect was calculated for each respondent. Frequency distribution, tables and percentages were used to describe the socio economic characteristics of the Catfish farmers in the study area.

Information sources; this was measured by considering the frequency of contact with the various sources of information, this was measured at four points namely not at all $=0$, rarely $=1$, frequently $=2$ and very frequently $=3$. The mean score of sources of information was later calculated.

PPMC was used to test significant relationship between socio economic characteristics of respondents and extension needs.

\section{Socio economic characteristics of the respondents \\ III. Results and Discussion}

Table 1 shows that majority of the respondents (70.6\%) were males. This shows that catfish production is male dominant in the study area. It was also shown that $60.3 \%$ of the sampled catfish farmers were between the ages of 30 and 50 years, with mean age of 42.5 . Thus majority of the sampled farmers were middle aged which could result in a positive effect on their production. The result also indicates that majority (74.8\%) of the respondents were married. This shows that respondents in the study area will have additional responsibility to their family. Moreover, the results further showed that only $24.4 \%$ had no formal education. In essence (75.6\%) of the respondents had one form of education or the other. This could enhance adoption of improve catfish production technologies through extension activities in the study area. Moreover, the results revealed further that $58.9 \%$ of the respondents had contact with extension agents in the study area. Table 1 further shows that more than half (57.4\%) of the respondents had household size of 6 and10 people living in their house with mean value of 6 people. This large family size can serve as sources of free and cheap labour.

\section{Sources of Information}

Table 2 shows catfish farmers source of information. The most important sources of information to catfish farmers on extension needs are Radio (2.82) followed by friends/relatives (2.8) and Extension agent (2.31). However the use of newspaper (1.27), telephone/GSM (1.21) and Bulletin/handbills (0.91) provide little source of information to catfish farmers. This result implies that catfish in the study area utilized different source of information on the basis of frequency of contact. This implies that catfish farmers utilize any information that will increase their production. The results show that radio is one of the effective medium of disseminating new agricultural innovation to the farmers. This is in line with Adekunle, (1996) and Nwachukwu 2003 findings which state that radio is the cheapest and quickest means of passing information to farmers and effective medium of disseminating agricultural information in Nigeria.

\section{Extension Service Needs}

Table 3 elicits the extension service needs of catfish farmers: Marketing, Time of Stocking, Sources of Credit, Record keeping and Time of feeding were ranked 1, 2, 3, 4 and 5 respectively. Least extension service needs were site selection, pricing, farmers association and general management with ranks of 10, 11, 12 and 13 .

The relative high rank of marketing may be due to the fact that marketing of produce plays on important role in agricultural development. This may encourage them to increase their production which will increase their income. 


\section{Constraints Faced By Catfish Farmers}

Table 4 shows constraints experienced by Catfish farmer during fish production. This includes poor weather (82.5\%) lack of credit (76.7\%), High Cost of feeds (58.3\%) poor transportation 56.7\%. The result reveals that majority of the respondents faced one problem or the other which may hinder their production.

\section{Relationship Between Socio-Economic Characteristics And Extension Service Needs}

The data in Table 5 show that age $(r=0.532)$, Gender $(r=0.195)$ and years of schooling $(r=0.324)$ showed that there were significant relationship between these variable and extension service needs.

This implies that as age increases there will be increase in extension services needs of respondents likewise other variables that are significant.

\section{Conclusion}

The study concluded that radio, friends and relatives and farmers association were major sources of information to catfish farmers in Ido Local Government area of Oyo State. Also various constraints faced includes poor weather, lack of credit and high cost of feeds. The following are recommended based on the findings.

$>\quad$ Mobilization of catfish farmers into economic groups, so as to improve their access to resources such as credit and agriculture extension trainings.

Provision of effective extension service to disseminate relevant and timely information.

$>$ Adequate technologies and best fish production practices should be encouraged. These will enhance production and productivity in the study area.

$>$ Extension agent should be encouraged to establish contacts with many more catfish farmer since this will likely encourage farmers to take the extension service needs on catfish farming.

Catfish farmers in the study area should intensify efforts to seek information relevant for their production.

Provision of basic amenities and necessary inputs that will make catfish farming easy should be provided for farmers in the study area.

Table 1: Socio Economic Characteristics of Respondents N-120

\begin{tabular}{|c|c|c|c|}
\hline Variable & Frequency & Percentage & Mean Value \\
\hline \multicolumn{4}{|l|}{ Gender } \\
\hline Male & 84 & 70.0 & \\
\hline Female & 36 & 30.0 & \\
\hline \multicolumn{4}{|l|}{ Age } \\
\hline Less than 21 & 5 & 4.2 & \\
\hline $21-30$ & 18 & 15 & \\
\hline $31-40$ & 36 & 30 & \\
\hline $41-50$ & 40 & 30.3 & 44 \\
\hline $51-60$ & 14 & 11.7 & \\
\hline Above 60 & 7 & 5.8 & \\
\hline \multicolumn{4}{|c|}{$\begin{array}{l}\text { Contact with extension } \\
\text { agent }\end{array}$} \\
\hline Yes & 72 & 60 & \\
\hline No & 48 & 40 & \\
\hline \multicolumn{4}{|c|}{ Household Size } \\
\hline $1-5$ & 36 & 30 & \\
\hline $6-10$ & 68 & 56.7 & 6 \\
\hline $11-15$ & 16 & 13.3 & \\
\hline \multicolumn{4}{|c|}{ Years spent in school } \\
\hline 0 & 29 & 24.4 & \\
\hline $1-6$ & 9 & 6.7 & \\
\hline $7-12$ & 40 & 33.6 & \\
\hline 13 and above & 42 & 35.6 & 13.2 \\
\hline
\end{tabular}

Source Field Survey: 2011 
Table 2: Distribution of Respondents Sources of Information

\begin{tabular}{|c|c|c|c|c|c|c|}
\hline \multicolumn{7}{|l|}{ Frequency of Contact } \\
\hline & Very freq. & Freq. & Rarely & at all Total & Mean score & Score \\
\hline Information Source & (F) $(\%)$ & (F) $(\%)$ & (F) $(\%)$ & (F) $(\%)$ & & \\
\hline Friends/Relatives & $96(80.0)$ & $24(20.0)$ & - & - & 336 & 2.8 \\
\hline Radio & $98(81.7)$ & $22(18.3)$ & - & - & 338 & 2.82 \\
\hline T.V & $32(26.7)$ & $13(10.8)$ & $45(35.5)$ & $30(25.0)$ & 135 & 1.13 \\
\hline Farmers Association & $38(31.7)$ & $47(39.2)$ & $13(10.8)$ & $19(15.8)$ & 185 & 1.54 \\
\hline Workshops & $15(12.5)$ & $27(22.5)$ & $36(30.0)$ & $42(35.0)$ & 135 & 1.13 \\
\hline Newspaper & $23(19.2)$ & $26(21.7)$ & $32(26.7)$ & $39(32.5)$ & 153 & 1.27 \\
\hline Extension Agent & $68(56.7)$ & $22(18.3)$ & $30(25.0)$ & & 278 & 2.31 \\
\hline Telephone/GSM & $17(14.2)$ & $33(27.5)$ & ) $28(23.3)$ & $42(35.0)$ & 145 & 1.21 \\
\hline Agric show & $22(18.3)$ & $47(39.2)$ & $33(27.5)$ & $18(15.0)$ & 193 & 1.61 \\
\hline Bulletin/Handbills & $18(15.0)$ & $25(20.8)$ & ) $35(29.1)$ & $42(35.0)$ & 109 & 0.91 \\
\hline
\end{tabular}

Source: Field Survey; 2011

Table 3: Distribution of Respondents According to Extension Service needs

\begin{tabular}{lcc}
\hline \multicolumn{1}{c}{ Extension Service Needs } & Frequency & Percentage \\
\hline Marketing & 1.74 & $1^{\text {st }}$ \\
Time of Stocking & 1.70 & $2^{\text {nd }}$ \\
Source of Credit & 1.61 & $3^{\text {rd }}$ \\
Record Keeping & 1.58 & $4^{\text {th }}$ \\
Time of Feeding & 1.51 & $5^{\text {th }}$ \\
Breeding of Fingerlings & 1.50 & $6^{\text {th }}$ \\
Feed Management & 1.44 & $7^{\text {th }}$ \\
Water conservation & 1.43 & $8^{\text {th }}$ \\
Catfish Techniques & 1.41 & $9^{\text {th }}$ \\
Site Selection & 1.40 & $10^{\text {th }}$ \\
Pricing & 1.29 & $11^{\text {th }}$ \\
Farmers Association & 1.23 & $12^{\text {th }}$ \\
General Management & 1.22 & $13^{\text {th }}$ \\
\hline
\end{tabular}

Source: Field Survey; 2011

Table 4: Distribution of Respondents According to Problem Faced

\begin{tabular}{|c|c|c|}
\hline Constraints & Frequency & Percentage \\
\hline Poor Weather & 75 & 62.5 \\
\hline Lack of Credit & 92 & 76.7 \\
\hline High cost of feeds & 70 & 58.3 \\
\hline Poor transportation & 68 & 56.7 \\
\hline Inadequate extension contact & 86 & 71.7 \\
\hline Poor management skills & 50 & 42.6 \\
\hline Lack of good practices & 56 & 46.7 \\
\hline Water Scarcity & 82 & 68.3 \\
\hline Poor Marketing Channel & 88 & 73.3 \\
\hline Inadequate Information & 63 & 52.5 \\
\hline Inadequate supply of good quality feeds & 73 & 60.8 \\
\hline
\end{tabular}

Source: Field Survey; 2011

Table 5: Summary of Pearson Correlation Showing Relationship between respondents selected personal characteristics and extension service needs.

\begin{tabular}{lcc}
\hline Variable & r-value & Remark \\
\hline Gender & $0.193^{*}$ & Significant \\
Age & $0.532^{* *}$ & Significant \\
Years spent in school & $0.324 * *$ & Significant \\
$*$ significant at 0.05 level & & \\
$*$ Significant at 0.01 level & & \\
\hline
\end{tabular}

Source: Field Survey; 2011 


\section{References}

[1]. Adebolu, V. O. and S. J. Ikotun, 2001 The Role of Research in Sustainable Fisheries Development. Towards Poverty Alleviation in Nigeria Proceedings of National Workshop for Agricultural and Rural Development in Nigeria Jos, Nigeria pp. 21 -33.

[2]. Adebowale, E. A; B. A. Ogunbode and R. A. Salawu (eds) 2006.

[3]. Farming System Research and Extension" Proceedings of the $13^{\text {th }}$ Annual Southwest Zonal OFAR and Extension Workshop. Institute of Agricultural Research and Training Obafemi Awolowo University Moor Plantation, Ibadan pp. 180

[4]. Adekunle, O. O. (1996): Radio Listenership pattern and knowledge of improved farm practices. Unpublished B. Sc Thesis Department of Agricultural Extension and Services; University of Ibadan, Nigeria.

[5]. Akinbode, A 1982 A Critical Analysis of the Management of Agricultural Extension in Nig. J Agric Administration, 10:45-60 Ala, A. L. and Umar, M. B. (2002): Analysis of small scale fish processing and Marketing in Argungu. Local Government Area of Kebbi State. Proceedings of the $7^{\text {th }}$ Annual Conference of Association of Nigeria, September $16^{\text {th }}-19^{\text {th }}$, 2002. University of Agriculture, Abeokuta, pp. 319

[6]. Food and Agricultural Organization FAO (1991) Fisheries Management: Technical Guidelines for Responsible Fisheries No 4, pp. 82 Wurts, W. A. 2004. Small- Scale and home use channel catfish farming in Kentury. World Aquacult, 35:8-9 